Al-Manhaj: Jurnal Hukum dan Pranata Sosial Islam

Vol. : : 2 (2), 2020, 255-282

P-ISSN : 2686-1607

E-ISSN : 2686-4819

\title{
ANALISIS SOSIOLOGI HUKUM ISLAM PADA WARUNG KOPI \\ LESEHAN YANG MEMPERKERJAKAN PEREMPUAN DEMI \\ MERAUP CUAN MAKSIMAL DI JALAN SUROMENGGOLO \\ PONOROGO
}

\author{
Roin Umaya, Nafi'ah \\ Institut Agama Islam Sunan Giri Ponorogo \\ email: mayadya18@yahoo.com,nafiah490gmail.com
}

\begin{abstract}
Maximizing "cuan or profit" in a business is a necessity. Traders often memorize all means in marketing their merchandise. Likewise, coffee sellers on Suromenggolo street or new road in Ponorogo Regency. In attracting customers they deliberately involve "sexy" women to sell their trade. This is a field of research, researchers go directly to the field to examine gaps that occur, data collection techniques using interviews, observation and data analysis. Various reasons for women to become coffee shop servants on Suromenggolo street, starting from the low level of education to being pushed aside, the difficulty of meeting family needs is a major factor. While in terms of the analysis the sociology of Islamic law, it was found that injustice in the process of cooperative interaction between coffee shop business owners and the female servants. Even though they are aware of the injustices and dishonesty that occur in reality they cannot fight the consequences of the agreed standard rules at the beginning.
\end{abstract}

Keywords: Sociology of Islamic law, Waiters of coffee shops, Cuan

Abstrak: Memaksimalkan cuan dalam sebuah bisnis maupun usaha merupakan keniscahyaan. Pedagang seringkali menghalkan 
segala cara dalam mamasarkan dagangannya. Begitu juga para penjual kopi di jalan Suromenggolo atau jalan baru Kabupaten Ponorogo. Dalam menarik pelanggan mereka sengaja melibatkan perempuan "seksi" untuk menjajalkan dagangnnya. Ini merupakan field research, yaitu peneliti terjun langsung ke lapangan untuk meneliti kesenjangan yang terjadi, teknik pengumpulan data menggunakan interview, observasi dan analisi data. Berbagai alasan para perempuan menjadi pelayan warung kopi di Jalan Suromenggolo mulai dari rendahnya tingkat pendidikan sampai terdesak akan sulitnya memenuhi kebutuhan ekonomi keluarga menjadi faktor utamanya. Sedangkan dari segi analisis sosiologi hukum Islam di temukan ketidakadilan dalam proses interaksi kerjasama antara pemilik usaha warung kopi dengan para pelayan perempuan tersebut. Meskipun mereka mengetahui atas ketidakadilan dan ketidakjujuran yang terjadi kenyataannya mereka tidak bisa melawan akhibat aturan baku yang sudah disepakati diawal.

Kata Kunci: Sosiologi hukum Islam, Pelayan warung kopi, Cuan

\section{PENDAHULUAN}

Manusia merupakan makhluk sosial yang saling membutuhkan satu sama lain untuk memenuhi kebutuhannya. Sebagai makhluk sosial ia membutuhkan manusia lain yang bisa mengakui keberadaannya. ${ }^{1}$ Interaksi sosial yang dilakukan oleh manusia itu sendiri terjadi karena kebutuhan manusia tidak bisa terpenuhi dengan kemampuannya sendiri dan harus melakukan kerjasama dengan kelompok lainnya. Manusia membutuhkan kebersamaan dalam kehidupannya. Dengan menjadi makhluk sosial ia juga memiliki interaksi dengan alam dan lingkungannya

1 Sanderson K Stephen, Sosiologi Makro Sebuah Pendekatan Terhadap Realitas Sosial (Jakarta: Rajawali Press, 2009), 78. 
berupa hubungan timbal balik antara satu dengan yang lainnya. Keterikatan sosial dalam segi posistif dan negatif. Sebagai makhluk ciptaan Tuhan yang berakal, manusia dituntut untuk bisa bersaing dengan yang lain agar tidak tertinggal perkembangan zaman. Allah SWT menciptakan manusia beraneka ragam dan berbeda-beda tingkat sosialnya. Ada yang kuat, ada yang lemah, ada yang kaya, ada yang miskin, dan seterusnya. Demikian pula Allah Subhanahu wa Ta'ala ciptakan manusia dengan keahlian dan kepandaian yang berbeda-beda. ${ }^{2}$

Dengan dasar penciptaan manusia yang memikul amanah berat menjadi khalifah di bumi, maka Islam memerintahkan umat manusia untuk saling ta'awun, saling tolong menolong, untuk tersebarnya nilai-nilai rahmatan lil alamin ajaran Islam. Islam menganjurkan umatnya untuk ta'awun dalam kebaikan saja dan tidak dibenarkan dalam kejahatan. Dengan adanya kemajuan zaman di era globalisasi ini semakin banyak kebutuhan sandang, pangan, papan ataupun juga pendidikan dan juga rekreasi. Dengan adanya kebutuhan- kebutuhan yang semakin mendesak mereka dituntut untuk bergerak demi memenuhi kebutuhan sehari-hari. Dari kreatifitas tersebut akan menimbulkan sebuah arus sosial di masyarakat baik secara induvidu maupun kelompok.

Semakin berkembangnya zaman menjadikan kebutuhan hidup lebih meningkat seperti yang dialami lapisan menengah ke bawah. Mau tidak mau mereka harus berlomba-lomba untuk mendapatkan peluang pekerjaan sesuai dengan keahliannya

2 Scharf R Betty, Kajian Sosiologi Agama (Jakarta: Pustaka Gramedia, 1995), 90. 
masing-masing. Dimana manusia tidak dapat jauh dari kebutuhan ekonomi, seperti yang dirasakan perempuan merupakan kaum yang identik dengan suka berbelanja. Di era sekarang, hal ini sudah hampir tidak diperhatikan apalagi praktek sosial, Di wilayah perkotaan orang-orang sibuk memikirkan kepentingannya pribadi dan tidak memperdulikan lingkungan sekitarnya seperti yang bisa lihat di daerah perumahan (real estate) semua hidup dengan serba individulaistik. $^{3}$

Dari Al-Miqdam ra, bahwa Rasulullah SAW bersabda:"Tidaklah seseorang mengkonsumsi makanan yang lebih baik dari makanan yang dihasilkan dari jerih payah tangannya sendiri. Dan sesungguhnya nabi Daud 'alaihissalam dahulu senantiasa makan dari jerih payahnya sendiri." (HR. Bukhari) ${ }^{4}$ Hadits tersebut menerangkan bahwa begitu banyak keutamaan dari bekerja untuk mencukupi kebutuhan diri dan keluarga. Dengan mencari nafkah yang halal dan pekerjaan yang sesuai dengan kemampuan, maka ia akan terhindar dari perbuatan yang tidak memuliakan kehormatannya. Bekerja dengan usaha yang halal, meskipun dipandang hina oleh manusia lebih baik dan mulia dari pada meminta-minta menjadikan beban bagi orang lain. Agar pekerjaan mendatangkan manfaat bagi orang lain, maka harus dipersiapkan dengan sebaik-baiknya. Dengan ini menjadikan hidup harus bekerja keras terutama kaum perempuan dalam

3 Takhesita Mastaka, Insan Kamil Pandangan Ibnu 'Arabi (Surabaya: Risalah Gusti, 2005), 112.

${ }^{4}$ HR. Bukhari, Kitab al-Buyu', Bab Kasbir Rojuli wa 'Amalihi Biyadihi II/730 no. 2072. 
berkembang zaman untuk memenuhi gaya hidup serba modern. Oleh karena itu mereka rela bekerja apapun demi memenuhi semua keinginan untuk mempertahakan hidup dengan berupaya memperbaiki perekonomian, salah satunya menjadi pelayan warung kopi. ${ }^{5}$

Persoalan kopi tidak hanya sebatas rasa dan aroma yang dimiliki. Kopi dan serba-serbinya biasa memunculkan takwil yang beragam. Kopi dengan berbagai macam rasa yang dipesan manis, pahit, setengah pahit, legit, bisa jadi merupakan gambaran nasib keseharian bagi meminumnya itu sendiri. Warung kopi bukanlah fenomena yang baru bagi masyarakat. Dengan adanya kemajuan teknologi informatika dan komunikasi yang merambah hampir ke segala aspek kehidupan, termasuk ke dunia bisnis warung kopi mempunyai sajian-sajian yang kian menggoda bagi para penikmat ataupun pemburu kopi, warung kopi yang kini telah dilengkapi dengan fasilitas wifi, layar lebar, atau tampil dengan nama lain seperti kantin, cafe, warung tenda, dan sebagainya, telah merubah persepsi masyarakat tentang kebiasaan minum kopi, yang kalau dulunya di dominasi oleh kalangan pria dewasa (bapak-bapak), lain perkara jika saat ini, dimana hampir semua kalangan, pria dan wanita, tua dan muda, banyak yang memilih stay disana untuk sekedar menikmati hidangan kuliner dan melepas penat, bahkan ada pula yang melakukan kegiatan-kegiatan penting seperti meeting, transaksi dan berdikusi dengan rekan kerja. ${ }^{6}$ 
Bukan pemandangan yang asing lagi, bila kita mengunjungi warung kopi di seputaran wilayah Ponorogo dan sekitarnya, banyak terlihat sederetan tenda-tenda, atau jejeran kursi dan meja, yang bukan hanya sekedar menawarkan kopi dan penganan kecil semata, melainkan telah berevolusi mengikuti arah kemajuan sarana pendukung yang mendampinginya, seperti layar lebar, wifi dan internet serta fasilitas pendukung lainnya.

Di satu sisi penambahan perangkat wifi atau layar lebar merupakan satu bagian dari "politik dagang" dalam merebut pasar konsumen, sehingga para pengusaha warung kopi atau cafe mengundang animo masyarakat dengan menawarkan fasiltas tambahan, wifi atau layar lebar, sebagai sebuah up-plus atau nilai lebih dalam mendatangkan pengunjung yang lebih ramai, yang tentunya bermuara pada pemasukan yang bertambah pula. ${ }^{7}$

Namun disisi lain, terlihat satu kenyataan yang cukup ironis, mengingat ketika pada waktu shalat, terlebih di waktu Maghrib, di mana banyak warung kopi yang masih berpenghuni. Ketika adzan berkumandang tetap saja aktivitas mereka berjalan seolah tiada terdengar apapun, padahal tidak demikian tuntunan dalam Islam. ${ }^{8}$

Atau bahkan waktu shalat jum'at (khususnya bagi kaum pria) seolah ada kecenderungan untuk tetap stay di warung kopi atau cafe dari pada bergegas untuk menunaikan ibadah jum'at,

7 Observasi, 9 Mei 2019.

${ }^{8}$ Hadist Riwayat Ibnu Majah 793, Ad-Daru Quthni 1/42. 
sebagaimana yang diperintahkan Allah dan termaktub dalam alQuran Surat Al-Jumu'ah: 9.

Adanya ayat tersebut maka dapat dijelaskan bahwasanya bagi kaum muslimin wajib memenuhi panggilan muazzin dan meninggalkan semua pekerjaan, seperti jual beli. Keadaan yang terjadi disaat ini sangat marak dan sudah menjadi kebiasaan yang dilakukan oleh pelaku bisnis. Dengan mengutamakan bermuamalah dan menghiraukan kewajibannya untuk beribadah.

Keadaan ini menjadi semakin miris dengan adanya "pembauran" antara kaum pria dan wanita, terlebih kaum muda (khsusnya kalangan pelajar dan mahasiswa) yang terlihat bak "tuan rumah", pemandangan tersebut dapat kita lihat hampir disetiap lokasi yang berbeda. Dalam hal satu ini, bukan berarti menggugat kehadiran kaum wanita ditengah kehidupan, akan tetapi ketiadaan pembatasan akan aturan mengenai pergaulan antara kaum pria dan wanita yang non-muhrim di tengah masyarakat luas. Agama Islam tidak melarang kaum wanita melakukan aktivitas di luar rumah, akan tetapi Islam memiliki aturan tersendiri dalam mengatur hal ini, bukan bermaksud menyampingkan hak-hak asasi kemanusian kaum wanita, akan tetapi sebaliknya, aturan dan ketentuan dalam Islam hendak menghormati dan melindungi kaum wanita sesuai dengan kodratnya.

Islam tidak melarang kaum wanita beraktivitas di luar rumah, atau bahkan melarang interaksi antara kaum laki-laki dan perempuan, akan tetapi Islam memberikan arahan dan tuntunan berikut dengan batasan-batasan bagi ummatnya dalam 
berinteraksi, termasuk dalam hal ini pedoman dalam pergaulan antara laki-laki dan perempuan, sebagaimana yang disebutkan dalam Firman-Nya (Q.S. An-Nur : 31).

Seperti yang diulas oleh penulis diatas hal ini dikarenakan kebutuhan baik primer maupun sekunder semakin meningkat sehingga beberapa pelaku atau oknum yang tidak bertanggungjawab memanfaatkan lahan pekerjaan sebagai pengusaha warung kopi lesehan jalan baru agar menghasilkan meteri secara instan dan cepat.

Fenomena warung kopi jalan baru merupakan contoh dari pencitraan pemilik warung kopi dengan cerdik memanfaatkan para perempuan sebagai stimulus warung kopi mereka. Bentuk bangunan warung kopi terbuat dari bambo, beratap terpal tenda, dan beralaskan tikar. Warung yang dibuat oleh para pelaku bisnis ini semakin marak bermunculan di pinggiran Kota Ponorogo.

Daerah warung remang-remang inilah yang dikenal oleh masyarakat sebagai warung jalan baru di mana penjualnya perempuan cantik-cantik dengan status belum menikah ataupun sudah menikah, ini memiliki gaya berpakaian serba minim dan ketat, ditambah lagi dengan adanya lampu malam tiba, seakan memberi signyal bahwa warung tersebut adalah warung yang mempunyai nilai lebih.

Berdasarkan uraian tersebut, maka dianggap perlu bagi penulis untuk mengadakan penelitian dengan pembahasan yang lebih jelas mengenai faktor yang mempengaruhi perempuan menjadi pelayan warung kopi lesehan di jalan baru Kabupaten 
serta bagaimana tinjauan sosiologi hukum Islam terhadap warung kopi yang memperkerjakan pelayan perempuan untuk meningkatkan pendapatan keluarga di jalan baru kabupaten ponorogo.

\section{FAKTOR-FAKTOR YANG MENDORONG PRAKTIK PELAYAN WANITA DI WARUNG KOPI LESEHAN JALAN BARU PONOROGO}

Aktivitas usaha dan bisnis dizaman sekarang sangat maju pesat. Yang dulu hanya sebatas kebutuhan pokok sekarang mulai berkembang dalam beberapa bidang dimasyarakat. Globalisasi ekonomi ditandai dengan pedagang bebas belum banyak memberikan ekonomi pada masyarakat umum. Salah satunya warung kopi lesehan yang sudah marak disetiap daerah. Untuk memancing minat para pelanggan mereka meperkerjakan perempuan sebagai pelayan.

Anggapan bahwa pedagangan bebas menguntungkan konsumen dalam bentuk pelayanan yang baik dan menjadi daya tarik bagi pelanggan. Untuk itu semua cara pendekatan diupayakan sehingga menimbulkan berbagai dampak, termasuk keadaan yang menjurus pada tindakan yang bersifat negatif bahkan tidak terpuji yang berawal dari ikhtikad tidak baik. Bagi mereka pelayan perempuan mampu berkomunikasi dengan baik, dimana akan menyebabkan pelanggan betah dan berlangganan mengunjungi warung kopi tersebut. Akan tetapi jika terjadi sebaliknya seperti tidak dilayani dengan baik, atau kurang ramah, pembeli akan pindah ketempat lain. Hal ini diucapkan oleh Pak Rudi supir Truck yang selalu menjadi pelanggan setia warung kopi 
yang berada disepanjang jalan Suromenggalan (jalan baru). ${ }^{9} \mathrm{Hal}$ senada diucapkan oleh Sujar seorang pelajar yang selalu mampir di warung kopi lesehan. ${ }^{10}$

Dari hasil wawancara peneliti dengan sebagian pelanggan warung kopi jalan baru. Tujuan utamanya selain untuk ngobrol atau berkumpul yaitu ingin melihat pelayannya yang cantik dan bisa berkenalan. Sehingga dengan begitu menjadikan pelanggan warung kopi lesehan ini menjadi betah dan nyaman berlama-lama santai dengan teman hingga tutupnya warung.

\section{ALASAN WANITA BEKERJA DEMI MEMBANTU PEREKONOMIAN KELUARGA}

Perhatian filosofi mengenai masalah-masalah sosial dan timbulnya analisis secara rasional atau ilmiah untuk pemecahannya memberikan dorongan bagi kelahiran disiplin sosiologi masa kini. Didalam sosiologi, studi tentang manusia telah dimasukkan dengan tema umum mengenai keluarga, seks dan jenis kelamin. ${ }^{11}$ Dalam kehidupan sehari-hari perempuan berada dalam suatu konteks beban ganda. Untuk memberikan pengasuhan yang tak berbayar dalam pelayanan dalam pekerjaan rumah tangga serta beban untuk memberikan kelangsungan hidup perekonomian melalui kerja upahan. Seperti menjadi pelayan warung kopi dimana pekerjaan tersebut seharusnya dilakukan

9 Rudi, "Wawancara” 16 Mei 2019.

10 Sujar, "Wawancara" 16 Mei 2019.

${ }^{11}$ Helen A, Moore Dan Jane C, Ollenburger, A Sociology of Women (PT Rineka Cipta, 1996), 1. 
oleh seorang laki-laki tetapi para pengusaha warung kopi yang ingin mendapatkan keuntungan lebih maka perempuan menjadi daya tariknya.

Seiring berkembangnya zaman dan era yang semakin maju kini perempuan diberi kesempatan serta peran yang sama dengan pria untuk membantu dalam pembangunan perekonomian. Program peningkatan ini terjadi karena di pasar kerja sudah cukup baik. Kebutuhan partisipasi sangat besar terutama ketika ditetapkannya model pembangunan yang berbasis masyarakat. Alasan utama yang mendasari kebijakan ini adalah sesungguhnya perempuan memegang sejumlah fungsi sentral dalam keluarga dan sekaligus merupakan sumber daya ekonomi yang tidak kalah pentingnya.

Fenomena yang terjadi dalam masyarakat semakin banyaknya perempuan membantu mencari tambahan penghasilan. Terdapat dua faktor penyebab peningktan jumlah calon tenaga kerja adalah pertama; kebutuhan yang tidak mampu dipenuhi dengan penghasilan suami yang dimana mendorongnya untuk membatu dalam memenuhi kebutuhan keluarga. Kedua, mereka yang memiliki pendidikan yang lebih tinggi atau keahlian khusus akan cenderung memilih untuk bekerja sebagai wanita karir.12

Kondisi ekonomi yang rendah akan mempengaruhi aktivitas ekonomi perempuan. Maksudnya semakin rendah pendapatan sebuah keluarga sementara tanggungan bertambah besar maka peran wanita sebagai the secondary worker. Sejak terbukanya kesempatan kerja bagi perempuan di luar peran 
rumah tangga, mereka mulai melaksanakan aktifitasnya sebagai ibu dan pencari nafkah.

Faktor yang menyebabkan perempuan menjadi salah satu partisipan dalam perekonomian antara lain; (1) Faktor ekonomi, (2) Tidak ada peluang kerja sesuai ketrampilan, (3) Mengisi waktu luang, (4) Adanya jumlah tanggungjawab keluarga. Adapun prinsip ketenaga kerjaan dalam Islam yang perlu diperhatikan oleh pelaku usaha sebagai berikut; (1) Kemerdekaan manusia, (2) Kemuliaan Derajat Manusia, (3) Keadilan dan anti diskriminasi, (4) Kelayakan upah pekerja.

Bekerja merupakan suatu bagian dari kehidupan manusia, karena harus memenuhi kebutuhan untuk menjalani hidupnya sehari-hari. Dalam Islam setiap manusia dibumi ini diajarkan untuk memiliki etos kerja yang tinggi. Sebab Islam adalah agama yang menghargai ketentuan dan kerja. Dilihat dari kacamata Islam yang selalu memberikan motivasi-motivasi terhadap laki-laki dan perempuan untuk dapat mengaktualisasikan diri secara aktif.

Oleh karena itu, Islam menghendaki agar wanita melakukan pekerjaan atau karier yang tidak bertentangan dengan kodrat kewanitaannya dan tidak mengurangi haknya di dalam bekerja, kecuali pada aspek-aspek yang dapat menjaga kehormatan dirinya, kemuliaannya dan ketenangannya serta menjaganya dari pelecehan dan pencampakan. Seperti yang telah dijelaskan dalam Al-Qur'an surat An-Nur ayat 31.

Pelayan warung kopi lesehan Jalan Baru Ponorogo sudah mempunyai ciri khas tersendiri. Menjadikan wanita pelayan 
warung kopi dengan mengharuskan berpakaian serba ketat tujuan mendapatkan banyak pelanggan merupakan tindakan yang menyimpang. Orang dikatakan menyimpang jika tindakan yang dilakukannya tidak sesuai dengan nilai-nilai dan norma sosial yang berlaku. Undang-undang yang telah ditetapkan serta ketentuan hukum Islam yang berlaku merupakan sebuah aturan atau norma sosial yang harus ditaati dan dilaksanakan. Karena aturan-aturan hukum tersebut mempunyai tujuan untuk kemaslahatan masyarakat bersama. ${ }^{13}$

Menjadi pekerja malam diwarung kopi yang selalu dikelilingi pelanggan laki-laki, merupakan resiko besar bagi wanita. Dimana menjadi sasaran utama dalam berjualan untuk mendapatkan banyak pembeli. Keadaan ini menjadi sangat miris dengan adanya "pembauran" antara kaum pria dan wanita, terlebih pada remaja. Terkait dengan fungsi perempuan untuk mendongkrak pendapatan, warung kopi tidak sembarang merekrut karyawan agar menjadi pelayan diwarungnya, melainkan berdasarkan kualifikasi tertentu. Selain itu, untuk lebih menyenangkan para pelanggan pemilik warung kopi mengharuskan pelayannya memakai pakaian yang dapat mencuri perhatian. ${ }^{14}$

Dengan demikian kopi dan perempuan disajikan sebagai satu paket layanan yang tidak terpisahkan. Maka tidak heran bila warung kopi lesehan jalan baru merupakan tempat kegemaran para pecinta kopi. Dengan begitu menjadikan pelaku usaha bisnis 
untuk menambah usaha lain, yang menurutnya dengan memperkerjakan wanita bisa mendapatkan keuntungan yang lebih besar lagi.

Beberapa warung kopi setia dengan fitrahnya yakni menjual kopi dan rokok sebagai menu utama. Tetapi tidak sedikit pula warung kopi yang memilih menggeser arah bisnisnya menjadikan sekedar sebagai sampul depan adapun sajian sebenarnya adalah mengutamakan pelayan perempuannya. Akibat pergeseran ini muncul penilaian kurang baik dari masyarakat terhadap warung kopi. Dulu sebelum muculnya warug kopi yang memperkerjakan pelayan perempuan, masyarakat masih memaknai sesuai fitrah. Tempat untuk bersantai sambil mencari dan menikmati secangkir kopi yang memiliki rasa khas tapi sekarang dengan munculnya warung kopi yang menyediakan pelayan perempuan, masyarakat cenderung memaknai sebagai ajang bisnis calo perempuan.

Diawali dari proses perekrutan pelayan warung kopi pada umumnya adalah perempuan yang tidak punya pilihan untuk bekerja ditempat lain. Hal ini ditunjukkan oleh adanya karakteristik umum berpendidikan rata-rata SD atau SMP, berasal dari keluarga kekurangan, sebagian memiliki pergaulan bebas, putus sekolah, bercerai dari suami dan harus menghidupi anaknya atau frustasi. Latar belakang tersebut sangat berkaitan dengan terbatasnya jaringan serta lemahnya informasi yang dimiliki.

Pendidikan penyiapan tenaga kerja sebagai kegiatan membimbing peserta didik sehingga memiliki bekal dasar berupa 
pembentukan sikap, pengetahuan, dan ketrampilan kerja. Peran pendidikan sangat besar dalam mempersiapkan Sumber Daya Manusia (SDM) yang mampu bersaing secara sehat. Dengan adanya jenjang pendidikan yang tinggi, maka mempermudah untuk mencari pekerjaan yang lebih baik. Namun kurangnya peluang dan pendidikan yang tidak cukup didapat oleh pelaku pelayan, mengharuskan untuk memilih lapang kerja yang seadanya. Seperti pelayan warung kopi lesehan, salah satu peluang kerja untuk memenuhi kebutuhan hidup.

Pendidikan menjadi acuan utama dalam mencari pekerjaan. Lulusan SD dan SMP disaat ini bukan menjadi batas minimal yang diperlukan oleh pelaku pemilik usaha. Yang dimana setiap orang memiliki kriteria untuk melakukan rekrut terhadap pekerja seperti yang dilakukan oleh pemiik warung kopi lesehan. Yang salah satunya harus mempunyai daya tarik untuk mengambil banyak pelanggan dan memberikan keuntungan usaha. Meskipun menjadi pelayan tidak membutuhkan jenjang pendidikan yang tinggi tetapi diharuskan mempunyai kemampuan dalam perdagangan dan pemasaran yang baik. Perempuan diwarung kopi merupakan daya pemicu untuk mendorong banyaknya pelanggan yang datang.

\section{TINJAUN SOSIOLOGI HUKUM ISLAM TERHADAP PELAYAN WARUNG KOPI}

Penempatan perempuan menjadi pelayan warung kopi merupakan kekuasaan mutlak pengusaha. Sebagai pekerja informal pelayan warung kopi pada umumnya tidak memiliki 
kontrak kerja tertulis sebagai bukti bahwa diantara pelayan dengan memilik warung terdapat hubungan kerja. Pelayan yang dirasa sudah cukup lama bekerja diwarung kopi biasanya akan dipindah di tempat lain dengan tujuan agar pelanggan tidak bosan. Oleh karena itu lazim dikatakan adanya "barang baru" yang menunjuk pada pelayan baru datang di warung kopi lain. Pelayan yang memiliki penggemar tetap biasanya akan dipertahankan oleh pemilik warung.

Oleh karena itu, sistem kerja yang sudah menjadi aturan baku dari pemilik warung yang diberikan kepada pelayan warung kopi, merupakan tindakan yang tidak sesuai dengan aturan bermuamalah. Dimana prinsip muamalah dilakukan atas dasar pertimbangan mendatangkan manfaat dan menghindarkan madlarat. Dengan memelihara nilai keadilan, kejujuran dan menghindari unsur-unsur penganiayaan, unsur-unsur pengambilan kesempatanm dalam kesempitan. Rasulullah SAW bersabda, "Sesungguhnya para pedagang akan dibangkitkan pada hari kiamat nanti sebagai orang-orang fajir (jahat) kecuali pedagang yang bertakwa pada Allah, berbuat baik dan berlaku jujur."

Dengan mengutamakan unsur yang berlaku dalam Islam, maka pelaku usaha warung kopi dapat menciptakan usaha yang bersyariah. Dengan mengutamakan prinsip dan hukum di dalam Islam. Tidak menjadikan pelayan sebagai bahan pancingan dengan aturan untuk memakai pakaian yang minim. Sebagaimana yang sudah menjadi ketentuan untuk menjadi pelayan warung kopi 
lesehan jalan baru Ponorogo. Hukum Islam melarang perbudakan semacam ini karena dalam ajaran Islam apabila melakukan suatu pekerjaan setiap orang dituntut untuk selalu bersikap jujur adil dan transparan dalam suatu pekerjaan.

Adapun alasan pelayan perempuan melakukan pekerjaan diwarung kopi khususnya mereka yang sudah berumah tangga yang dimana harus mampu mencukupi kebutuhan sehari-hari guna untuk kelangsungan hidup. Oleh sebab itu mereka dituntut untuk bekerja keras. Tujuan peran pelayan wanita yang bekerja di warung kopi dalan anyar hanya untuk mencari nafkah yang tak lain yaitu adanya harapan peningkatan perekonomian keluarga serta memperoleh kebahagiaan. Upaya terpenuhinya kebutuhan tersebut secara umum dapat dicapai melalui upaya kerja keras keluarga. Dengan bekerjanya wanita menjadi pelayan warung kopi untuk membantu pendapatan keluarga. Interaksi yang berlangsung diantara penjual dan pembeli merupakan hubungan sosial dan tindakan yang ada.

Pendapatan keluarga dapat dipahami sebagai sebuah aktifitas dalam memenuhi keperluan hidup. Upaya untuk memenuhi kebutuhan tersebut telah diabadikan dalam Al-Qur'an sebagai betuk penghargaan dalam mempertahankan kelangsungan hidup. Islam memang tidak melarang wanita untuk bekerja bahkan dalam agama Islam membenarkannya dengan menganjurkan jika dalam keadaan darurat. Dalam Al-Qur'an juga menjelaskan bahwa setiap manusia hendaknya mencari rezeki dengan cara sebagaimana yang disebutkan dalam firman Allah 
SWT dalam Surat al-Jumu'ah:10. Dalam hadits, Rasulullah SAW memuji orang yang makan dari hasil jerih payahnya sendiri. ${ }^{15}$

Melihat fenomena tersebut, peneliti berusaha menggali dari aspek sosiologi bahwa bekerja menjadi pelayan warung kopi merupakan pekerjaan yang diperbolehkan, apabila yang menjadi tujuannya untuk mencari nafkah, dan tau batasan-batasan dengan lawan, seperti halnya pangkon, peluk ataupun segala aktifitas yang menjurus perilaku mesum.

Sebagai wanita yang bekerja di malam hari dan bebas bergaul maka harus tau aturan dalam islam itu sendiri. Dengan adanya perubahan sikap dan kebiasaan yang terjadi pada pelayan warung kopi sering kali di klaim sebagai keberhasilan Barat dalam upaya penegakan hak asasi manusia dan kesetaraan gender.

Allah SWT menetapka sanksi dalam hukum agar hal tersebut dipatuhi, demi kemaslahatan itu sendiri. Karena tujuan ditetapkan sanksi atau hukuman untuk memelihata dan menciptakan kemakmuran manusia serta menjaga hal-hal yang buruk. Meskipun demikian, wanita yang bekerja dan mendapatkan gaji juga perlu memperhatikan hukum Islam yang membatasi kegiatan yang terlarang.

Selain prinsip-prinsip juga harus memenuhi asas hukum Islam yang dijadikan sebagai pedoman. Seperti halnya meniadakan kesulitan dalam bekerja dan pengupahan, sesuai dengan kebutuhan manusia yang aman dan sesuai dengan hukum Islam

15 HR Bukhari no. 1966 dari Al Miqdam bin Ma'diyakrib Radhiyallahu ‘anhu 
yang berlaku. Segala macam bentuk kegiatan diwarung kopi, dalam Islam dianjurkan sesuai dengan rukun dan syarat yang telah ditentukan dan dilarang perdagangan yang terdapat tidakan kekerasan, perbudakan atau sesuatu yang menyebabkan salah satu pihak merasa dirugikan. Dalam Islam wanita diperbolehkan bekerja selama pekerjaannya itu tidak mengesampingkan keluarganya. Seperti yang telah diterangkan dalam al-Qur'an Surat An-Nisa': 32.

Dari ayat diatas menunjukkan bahwa kaum laki-laki memperoleh bagian dari hasil yang mereka usahakan, dan kaum wanita memperoleh pula bagian dari yang mereka usahakan. AlQur'an menegaskan bahwa laki-laki dan wanita sama-sama memperoleh hak mendapatkan pekerjaan yang layak, sehingga mereka juga memperoleh upah kerja yang layak pula. Hukum wanita bekerja dalam islam dapat menjadi wajib apabila tidak ada orang lain dalam keluarga yang dapat menafkahinya.

Syakh Abdul Aziz Bin Baz mengatakan: "Islam tidak melarang wanita untuk bekerja dan bisnis, karena Allah mensyariatkan dan memerintahkan hambanya untuk bekerja". Dalam Firman Allah SWT dalam Surat at-Taubah: 105.

Oleh karena itu, ada kecenderungan bahwa semakin rendah tingkat sosial ekonomi suatu masyarakat maka tingkat pertisipasi angkatan kerja perempuan semakin meningkat. Perubahan sosial dalam pengorganisasian tenaga kerja di masyarakat telah menyebabkan perubahan hubungan atara pelaku usaha dalam perekonomian. 
Dengan kurangnya pengalaman dan pendidikan menjadi faktor perubahan sosial yang terjadi di masyarakat kecil, dimana wanita tidak diharuskan untuk bekerja ditengah malam dengan berbagai unsur yang menjadikan alasan. Seorang wanita boleh saja bekerja jika ada satu dari sejumlah keadaan yang memperbolehkan perempuan bekerja diluar rumah sehingga dikatakan bahwa wanita yang bekerja itu harus memenuhi syaratsyarat tertentu. Dengan demikian tidak berakibat buruk bagi diri sendiri dan keluarganya. Seperti yang dijelaskan diawal bahwa Islam memberikan apresiasi tinggi tehadap aktivitas kerja dan orang-orang yang bekerja.

Perubahan tidak hanya terjadi dalam bidang teknologi dan industri saja, tapi juga di ikuti oleh kehidupan sosial termasuk perubahan pola pikir, gaya hidup, perilaku, adat kebiasaan dan adat budaya. Perempuan yang dulunya mengalami diskriminasi dalam hal pendidikan dan ketrampilan, kini telah mendapatkan hak dan kesempatan yang sama. Kini pelaku usaha banyak membuka peluang kerja untuk wanita, dari remaja, ibu-ibu ataupun yang masih dibawah umur.

Dalam kehidupan sehari-hari tidak mudah untuk menentukan letak garis pemisah antara perubahan sosial dengan adat budaya. Biasanya kedua gejala tersebut dapat ditemukan hubungan timbal balik oleh keduanya. ${ }^{16}$ Perubahan terjadi dengan sendirinya tanpa rencana atau kehendak tertentu. Perubahan

16 Soekanto Soerjono, Sosiologi Suatu Pengantar (Jakarta: Rajawali Press, 1987), 268. 
tersebut terjadi karena usaha masyarakat untuk menyesuaikan diri dengan keperluan, keadaan, kondisi baru yang timbul sejalan dengan perkembangan masyarakat.

Disamping itu pekerja perempuan pelayan warung kopi juga harus sadar dengan hak perlindungan kerja. Dengan demikian ketentuan hukum terkait dengan jaminan kesusilaan dan keamanan mampu dijalankan dengan baik oleh pelaku usaha warung kopi,tanpa merugikan kedua belah pihak yang bersangkutan. Untuk mencapai keamanan dan kesejahteraan maka harus memenuhi kebutuhan hidup dengan baik dengan mengikuti aturan yang sudah menjadi kesepakatan kerja bersama.

Ajaran Islam menganjurkan untuk selalu berbuat baik termasuk kepada pekerja. Sehingga tidak dibenarkan apabila peraturan yang mengatur tentang hubungan pekerja dengan majikan merugikan satu pihak dan menguntungkan pihak lain. Oleh karena itu maka peraturan-peraturan yang dibuat pengusaha hendaknya seimbang dengan pekerjaan yang dilakukan.

Ayat ini dengan tegas melarang agar tidak merugikan manusia pada hak-haknya dan tidak membuat kerusakan di bumi. Pada dasarnya prinsip hubungan antar manusia menurut islam adalah tidak boleh menzalimi dan tidak boleh dizalimi dengan cara apa pun dan dalam bidang apa pun. Dalam ketenagakerjaan pelaku bisnis juga harus menempatkan hak-hak dan kewajiban yang imbang. Dimana pekerja bisa mendapatkan haknya dalam upah, jam kerja, maupun tunjangan yang diberikan. Dalam islam juga menjelaskan bahwasanya sesama muslim harus saling menghargai, mengormati dan juga adil dalam segala hal. 
Dari ayat diatas dapat dijelaskan bahwasanya tenaga kerja merupakan sumber terpenting dalam kegiatan usaha yang dimana membantu bisnis menjadi lebih berkembang. Dengan memberikan upah atau barang lain dalam bentuk menghargai jasa dan usaha yang telah dilakukan dalam pekerjaan.

Berdasarkan penelitian wawancara, observasi dan dokumentasi di warung kopi lesehan dalan anyar ini menunjukkan bahwa kodrat perempuan mengalami perbahan. Aktifitas seharihari hanya melaksanakan pekerjaan domestic. Namun saat ini seiring berkembangnya zaman situasi dan kondisi yang berbeda banyak yang memutuskan untuk bekerja memenuhi kebutuhan nafkah keluarga.

Oleh karena itu, sudut pandang sosiologi hukum Islam diperlukan untuk membahas mengenai pengaruh timbal balik antara hukum dan realitas di masyarakat. Seperti keterangan Weber yang tak memisahkan antara struktur sosial dan pranata sosial karena keduanya sama-sama membantu untuk membentuk tindakan sosial. Sehingga sebuah tindakan dianggap sebagai tindakan sosial atau tidak tergantung dari ada atau tidaknya tujuan dibalik tindakan tersebut memenuhi arti subjektif bagi dirinya dan diarahkan pada orang lain. Hubungan antara perubahan sosial dan hukum Islam merupakan hubungan interaksi yang terdapat pengaruh sosial terhadap perubahan hukum, sementara disisi lain perubahan hukum juga berpengaruh terhadap perubahan sosial. Oleh karena itu, adanya perubahan sosial akan membawa perubahan hukum dan sebaliknya. 
Ketergantungan dan keterikatan antara sosial dan hukum sebagaimana disebut membawa perubahan hukum sosial. Soekanto mengatakan bahwa terjadinya interaksi adalah fenomena nyata. ${ }^{17}$

Sosiologi hukum Islam memandang sejauh mana hukum Islam mempengaruhi tingkah laku sosial baik secara tekstual maupun konteksual oleh umatnya. Hukum Islam berfungsi ganda, yaitu sebagai hukum ia berusaha mengatur tingkah laku manusia (umat Islam) sesuai dengan citra Islam dan sebagai norma ia memberikan legitimasi ataupun laranganlarangan tertentu dengan konteks spiritual. ${ }^{18}$ Menurut pandangan Ibnu Qayyim, "Perubahan dan perbedaan fatwa berdasarkan perubahan waktu, tempat, kondisi dan niat serta adat."19

Maksud perubahan disini bukan berarti seluruh fatwa mengenai hukum syari'ât mesti disesuaikan dengan zaman, tempat dan tradisi. Fatwa bersifat dinamis, karena merupakan respon terhadap perkembangan baru yang dihadapi masyarakat. Munculnya fenomena sosial tersebut tentu membutuhkan format hukum baru yang mampu membuat masyarakat menjadi taat. Maksudnya perubahan hukum itu untuk memelihara kemaslahatan umat Islam dengan jalan memberikan hukuman

17 Soerjono Soekanto, Beberapa Permasalahan dalam Kerangka Pembangunan di Indonesia (Jakarta: Yayasan Penerbit UI, 1975), 108-109.

18 Sudirman Tebba. Sosisologi Hukum Islam (Yogyakarta: UII Press, 2003), 1-2.

19 Rusdaya Basri, "Ibnu Qayyim Al-Jauziyah Tentang Pengaruh Perubahan Sosial”, Al-Manahij, Vol. IX No. 2, 196. 
yang lebih berat guna mencegah semakin tersebarnya perbuatan yang dilarang.

Ibnu Qayyim membagi hukum menjadi dua macam: pertama, hukum yang baku dan tidak berubah karena zaman, tempat dan ijtihâd ulama. Seperti perkara-perkara yang wajib dan haram, sanksi bagi tindak pidana yang telah ditetapkan oleh syari'ât dan lain-lain. Kedua, hukum yang disesuaikan dengan tuntutan kemaslahatan pada tempat dan keadaan tertentu. Jika dikaitkan dengan masalah pekerjaan wanita, sebenarnya hukum Islam berkembang sesuai dengan perkembangan zaman. Namun kenyataannya, ketentuan hukum Islam yang berlaku tidak berjalan semestinya. Pemeliharaan norma-norma tidak berjalan yang menyebabkan ketidakseimbangan gender dalam sistem sosial yang ada

Norma-norma yang dimaksud adalah ketentuan hukum dalam hal ini undang-undang, maupun ketentuan hukum Islam tentang derajat seorang perempuan. Dimana norma-norma yang harusnya ditaati tetapi diabaikan begitu saja dan seolah tidak berpengaruh terhadap fenomena perempuan dalam berkerja untuk mencari nafkah di jam-jam tertentu, seperti malam hari sampai larut malam. Disisi lain mereka tahu adanya Hukum Islam yang membatasi perempuan untuk bekerja terutama keluar dari rumah. Namun karena faktor perekonomian di lingkup keluarga, maka hal itu sudah dianggap sebagai kewajaran.

Setelah mencermati analisis diatas, maka kita dapat mengetahui bahwa wanita yang melakukan pekerjaan sebagai 
pelayan warung kopi dimalam hari untuk mencari nafkah di dalan anyar Kabupaten Ponorogo dalam pandangan sosiologi diperbolehkan. Namun dalam konteks hukum Islam sangat tidak dibenarkan. Karena pada dasarnya terdapat tindakan yang dimana merugikan pelayan perempuan warung kopi yang dipakai utuk tujuan tertentu yaitu sebagai daya pikat pelanggan demi mencapai keuntungan. Serta aturan hukum Islam yang dibuat tidak dihiraukan dan diabaikan begitu saja, hal ini menyebabkan sistem sosial tidak berjalan dengan semestinya.

Kemaslahatan merupakan tujuan utama diturunkannya syariat untuk umat manusia, apalagi dalam urusan kemanusiaan. Setiap permasalahan yang timbul di tengah masyarakat harus disikapi dari sudut pandang yang obyektif. Harus dicari akar pokok masalah mengapa sampai terjadi hal yang demikian. Sehingga kita lebih berhati-hati dalam menjustifikasi hukum atas sebuah persoalan. Karena persoalan kadang tidak selesai begitu saja hanya sebatas justifikasi hukum haram dan halal saja dan boleh atau tidak.

\section{KESIMPULAN}

Dari data yang diperoleh peneliti yang didapatkan paparan diatas maka dapat disimpulakan dari peneliti ini yakni : Latar belakang yang menjadikan faktor perempuan bekerja sebagai pelayan warung kopi disebabkan oleh beberapa alasan, diantaranya: karena kebutuhan ekonomi keluarga, pendidikan, kurangnya skill dalam menciptakan usaha sendiri, dan kurangnya lapangan pekerjaan dalam daerah. Praktik pelayan perempuan di 
warung kopi dalan anyar di Kabupaten Ponorogo sudah menjadi hal biasa di masyarakat sekitar. Pelayan perempuan warung kopi, jika dikaitkan dengan sosiologi hukum Islam, pelayan perempuan warung kopi lesehan yang sudah mengetahui ketentuan hukum Islam yang berlaku namun kenyataanya tetap melakukan kegiatan tersebut karena terikat aturan yang disepakati antara kedua pihak yang bersangkutan.

\section{DAFTAR PUSTAKA}

Abdulsyani. Sosiologi Skematik, Teori dan Terapan. Jakarta: Bumi Aksara, 2002.

Aditus, Editus dan Jaelani, Libertus. Hak-Hak Pekerja Perempuan, Tanggerang: Visi Media, 2006.

Alim, Agus. Perubahan Sosial Sketsa Teori dan Refleksi Metodologi Kasus Indonesia. Yogykarta: PT Tiara Wavana, 2002.

Basri, Rusdaya. "Ibnu Qayyim Al-Jauziyah Tentang Pengaruh Perubahan Sosial", Al-Manahij, Vol. IX No. 2., 2015.

Betty, Scharf R. Kajian Sosiologi Agama. Jakarta: Pustaka Gramedia, 1995.

Cohen, Bruce J. Sosiologi Suatu Pengantar. Jakarta: Rineka Cipta, 1992.

Diah, Perwira Kiki. "Analisis Customer Relations Kedai Kopi

Espresso Bar di Yogyakarta Dalam Meningkatkan dan Meningkatkan Konsumen". Skripsi. Universitas

Pembangunan Nasional Veteran Yogyakarta, 2012.

Effendi, Winda Roselina. "Hak Asasi Manusia: Studi Hak-Hak Buruh di Indonesia Human Right: AStudy About Labor Righ in Indonesia", Jurnal Dimensi Vol. 6 No. 1, 2002.

Fatkhul, Muslimin. "Geliat Bisnis Warung Kopi Pangkon Di Sekitar Lokasi Wisata Religius Makam Sunan Drajad Di Desa Drajad Kecamatan Paciran Kabupaten Lamongan”, Skripsi Universitas UIN Sunan Ampel Surabaya, 2014. 
Helen A, Moore Dan Jane C, Ollenburger. A Sociology Of Women. PT Rineka Cipta, 1996.

Iskandar. Metodologi Penelitian Kualitatif. Jakarta: Gaung Persada, 2009.

Jurdian, Doni. Pekerja Tetap, Kontrak, Freelace, Outsourcing. Jakarta: Dunia Cerdas, 2014.

Kartono, Kartini. Metodologi Riset Sosial. Bandung: Bandar Maju, 1986.

Kementerian Agama RI. Al-Qur'an Terjemah, Bandung: Sygma Creative Media Corp, 2014.

Mastaka, Takhesita. 2005. Insane Kamilpandangan Ibnu 'Arabi. Risalah Gusti. Surabaya, 2005.

Nana, Sukmadinata Syaodih. Metode Penelitian Pendidikan, Bandung: PT. Remaja Posdakarya, 2012.

S. Mulyadi. Ekonomi Sumber Daya Manusia Dalam Perspektif Pembangunan. Jakarta: Rajawali Pers, 2012.

Saebani, Beni Ahmad. Sosiologi Hukum. Bandung: Pustaka Setia, 2006.

Sari, Shinta Kumala. "Perlindungan Hukum Bagi Pekerja Dalam Perjanjian Kerja Waktu Tertentu (PKWT) Di CV. Shofa Marwah", Skripsi Fakultas Hukum Universitas Hukum Universitas Sebelas Maret Surakarta, 2011.

Soekanto, Soerjono. Beberapa Permasalahan dalam Kerangka Pembangunan di Indonesia. Jakarta: Yayasan Penerbit UI, 1975.

Soekanto, Soerjono. Pengantar Sosiologi Hukum. Jakarta: Bhratara Karya Aksara, 1997.

Soekanto, Soerjono. Pokok-Pokok Sosiologi Hukum. Jakarta: Rajawali Pers, 2014.

Soerjono, Soekanto. Sosiologi Suatu Pengantar. Jakarta: Rajawali Press, 1987.

Sonny, Sumarsono. Ekonomi Managemen Sumber Daya Manusia dan Ketenagakerjaan. Yogjakarta: Graha Ilmu, 2003.

Stephen, Sanderson K. Sosiologi Makro Sebuah Pendekatan Terhadap Realitas Sosial Jakarta: Rajawali Press, 2009.

Sugiyono. Metode Penelitian Pendidikan. Bandung: Alfabeta, 2006.

Syam, Nur. Bukan Dunia Berbeda Sosiologi Komunitas Islam. Surabaya: Jenggala Pustaka Utama, 2004.

Syamsuddin, Abdullah. Agama dan Maysrakat (Pendekatan Sosiologi Agama). Jakarta: Logos Wacana Ilmu, 1997. 
Tebba, Sudirman. Sosisologi Hukum Islam. Yogyakarta: UII Press, 2003.

Vivin, Marastika. "Gaya Hidup Minum Kopi Pemuda di Kota Palembang (Studi Kasus pada Pemuda Penikmat Kopi di Starbucks Coffee Palembang Icon Mall)". Jurnal. Universitas Sriwijaya Inderalaya, 2015.

Yahya, Mukhtar dan Fathurrahman. Dasar-dasar Pembinaan Hukum Fiqh Islam. Bandung: PT Al-Ma'arif, 1996.

Zenda, Rizki Herdian \& Suparno. "Peran Sektor Terhadap Penyarapan Tenaga Kerja di Kota Surabaya", Jurnal Ekonomi dan Bisnis Vol 2 No. 1, 2014. 